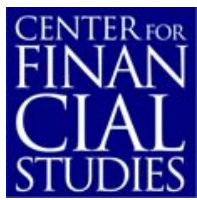

No. $2011 / 22$

Monetary Policy and TIPS Yields Before the Crisis

Stefan Gerlach and Laura Moretti 


\section{Center for Financial Studies}

The Center for Financial Studies is a nonprofit research organization, supported by an association of more than 120 banks, insurance companies, industrial corporations and public institutions. Established in 1968 and closely affiliated with the University of Frankfurt, it provides a strong link between the financial community and academia.

The CFS Working Paper Series presents the result of scientific research on selected topics in the field of money, banking and finance. The authors were either participants in the Center's Research Fellow Program or members of one of the Center's Research Projects.

If you would like to know more about the Center for Financial Studies, please let us know of your interest.

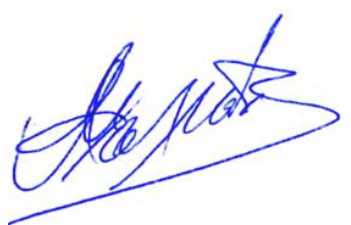

Prof. Michalis Haliassos, Ph.D.
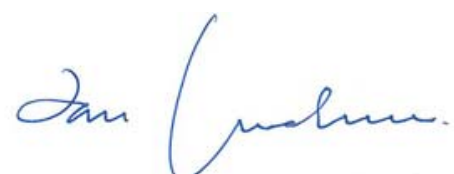

Prof. Dr. Jan Pieter Krahnen

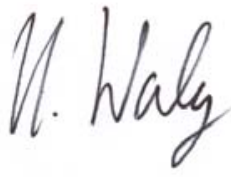

Prof. Dr. Uwe Walz 


\title{
Monetary Policy and TIPS Yields Before the Crisis*
}

\author{
Stefan Gerlach ${ }^{1}$ and Laura Moretti ${ }^{2}$
}

August 24, 2011

\begin{abstract}
:
We make three points. First, the decade before the financial crisis in 2007 was characterized by a collapse in the yield on TIPS. Second, estimated VARs for the federal funds rate and the TIPS yield show that while monetary policy shocks had negligible effects on the TIPS yield, shocks to the latter had one-to-one effects on the federal funds rate. Third, these findings can be rationalized in a New Keynesian model.
\end{abstract}

JEL Classification: E43, E52, E58

Keywords: Monetary Policy, Long Real Interest Rates, TIPS

* We are grateful to Petra Gerlach for comments.

1 Institute for Monetary and Financial Stability and CEPR. Contact Address: IMFS, Goethe University, Grüneburgplatz 1, 60323 Frankfurt, Germany, E-mail: stefan.gerlach@wiwi.uni-frankfurt.de 


\section{INTRODUCTION}

Many observers have argued that too expansionary monetary policy set the stage for the financial crisis that erupted in August 2007. Low short-term interest rates led financial institutions to raise leverage and provided investors with incentives to hold riskier assets, including structured products, that promised higher returns at little extra risk.

However, while policy-controlled interest rates were undoubtedly low, the issue is whether they were too low given macroeconomic conditions. John Taylor (Taylor 2007, 2008) argued that the Federal Reserve made a policy mistake in the sense that it set interest rates much below those suggested by the Taylor rule, which appears to have had good stabilizing properties. Similarly, Lombardi and Sgherri (2007) estimate that the Fed cut interest rates below the natural rate between 2001 and 2005.

By contrast, Bernanke (2010) shows that monetary policy was not unusually expansionary given the weakness of the economy. Furthermore, Bernanke (2005) suggests that savingsinvestment imbalances led to a decline in long real interest rates across the world, depressing nominal interest rates along the yield curve. However, Obstfeld and Rogoff (2009) argue that the data do not support this claim for the period 2000-2005 and the initial fall in real interest rates is more closely related to the end of the productivity boom of the 1990s. Low policy-controlled interest rates may thus simply have reflected this decline in real interest rates.

In this paper we seek to distinguish between these hypotheses. We note from the outset that macroeconomic theory implies that monetary policy has at most temporary real effects and cannot explain a persistent fall in long real yields. It seems implausible that reductions in the federal funds rate - a nominal overnight rate - can have depressed 10year real interest rates over a decade.

\section{SHORT NOMINAL VS. LONG REAL InTEREST RATES}

Next we review the behavior of the federal funds rate and the yield on 10-year Treasury Inflation-Protected Securities (TIPS) in the US before the crisis. We use data between 
January 1999, when the TIPS data begins, and July 2007, that is, the last month before the crisis started.

Figure 1 shows that the Federal Reserve cut the federal funds rate aggressively after the "dot-com" crash in 2000 and maintained it at 1\% until June 2004, when interest rates were gradually increased to reach $5.25 \%$ in June 2006. The fall by half of the TIPS yield from about $4 \%$ in 2000 to around $2 \%$ in 2005, after which it rose somewhat towards the end of the sample, is striking, as is the limited correlation between the two interest rates.

\section{A VAR ANALYSIS}

Before turning to our theoretical analysis, we estimate a four-variable VAR that comprises the growth rate over twelve months of a Coincident Economic Activity Index, as a measure of real economic conditions, the core personal consumption deflator, the federal funds rate and the yield on ten-year TIPS, as a measure of the real interest rate. We ask two questions. First, did the cuts in the federal funds rate depress long real yields? Second, how did the decline in the long real yields impact on the federal funds rate?

In order to identify the shocks, the variables were ordered as above. Implicitly, we assume, as is common on the VAR literature, that changes in the federal funds rate do not impact on economic activity or inflation instantaneously, but that the converse may be true. The ordering the TIPS yield after the federal funds rate implies that monetary policy does not respond immediately to innovations in the yield on TIPS, and thus attributes any withinperiod correlation between the two variables to responses of the yield on TIPS to federal funds rate. This assumption maximizes the explanatory power of monetary policy for long real yields. ${ }^{1}$

Estimation is done on monthly data from May 1999 to July 2007 using a VAR(4) specification as suggested by Akaike and Schwartz information criteria, tests for lag length and for serial correlation of the residuals. We incorporated dummies to account for effects of the terrorist attacks on September 11, 2001 and to account for "Y2K."

\footnotetext{
1 The residuals are virtually orthogonal so the choice of ordering is irrelevant. Not surprisingly, the highest correlation (0.07) is between the federal funds rate and the yield on TIPS.
} 
Figure 2 shows the impulse responses arising from the VAR. In the interest of brevity, we show only the responses of the federal funds rate and the yield on 10-year TIPS to monetary policy shocks and shocks to the yield on TIPS. In the upper-left corner we see that a monetary policy shock raises the federal funds rate immediately by about 10 basis points and that the effect increases for about six months before the rate gradually falls and returns to zero after about 18 months. In the lower left-hand side we see that the yield on 10-year TIPS does not respond to the tightening of monetary policy, supporting the notion that monetary policy has no permanent effect on real variables.

The lower right-hand panel shows that the responses of the yield on ten-year TIPS to real interest rate shocks are very persistent: the yield on TIPS rises by about 15 basis points immediately and remains 5 basis points above the initial level after two years. More interestingly, the upper-right panel of the figure indicates that after a shock to the TIPS yield, the federal funds rates rises gradually and reaches about 10 basis points after ten months. Subsequently it falls slowly and reaches a level about 5 basis points above the initial level after two years.

Thus, monetary policy shocks have apparently no effect on long real interest rates, but movements in long real interest rates seem to induce one-to-one responses of the short nominal interest rate after some period of time. In turn, this suggests that monetary policy played a limited role in setting the stage for the crisis by depressing long real rates. Next we interpret these findings.

\section{A NeW KeyNESIAN Model}

Since Obstfeld and Rogoff (2009) show that long indexed yields fell across the world in the year prior to the crisis, in the interest of brevity we think of the world as a closed economy. While this does allow us to study short and long, nominal and real interest rates that are the focus of this paper, it does not permit us to study regional current account imbalances.

Following Woodford (2003), we refer to the (one-period) natural real interest rate as the Wicksellian interest rate and analyze how a shock to it impacts on the short-term interest 
rate set by the central bank, the long-term real interest rate, the inflation rate and the output gap.

We consider the canonical three-equation New Keynesian model. First, we use the hybrid version of the Phillips curve as in Gali and Gertler (1999)²:

$$
\pi_{t}=\beta \omega \phi^{-1} E_{t} \pi_{t+1}+\theta \phi^{-1} \pi_{t-1}+\kappa \tilde{y}_{t}
$$

where $\tilde{y}_{t}$ denotes the output gap $\tilde{y}_{t}=y_{t}-\bar{y}_{t}{ }^{3}$ Next we have the dynamic IS/AD curve:

$$
\tilde{y}_{t}=E_{t} \tilde{y}_{t+1}-\frac{1}{\sigma}\left(i_{t}-E_{t} \pi_{t+1}-\tilde{r}_{t}\right)
$$

where $\tilde{r}_{t} \equiv \sigma E_{t}\left(\bar{y}_{t+1}-\bar{y}_{t}\right)+\mu_{t}$ is the Wicksellian real interest rate, or the interest rate consistent with output being equal to the flexible-price equilibrium level, and $\mu_{\mathrm{t}}$ an exogenous shock. Policy makers do not to know the Wicksellian interest rate and assume that it is constant. Thus, the monetary policy rule is of the standard Taylor rule form:

$$
i_{t}=\phi_{\pi} \pi_{t}+\phi_{y} \tilde{y}_{t}+v_{t}
$$

This model captures the two monetary policy mistakes discussed in the introduction. Interest rates can be set too low, given inflation and the output gap, in the sense that there is a series of large, negative $v$-shocks. Alternatively, policy makers may fail to perceive a temporary, but persistent, $\mu$-shock to the Wicksellian interest rate.

In Figure 3 shows the effect of a negative $v$-shock. We assume that the shock obeys an AR(1) process with a parameter of 0.5 , as in Walsh (2010). In response, the output gap and inflation rise. A monetary policy error of the Taylor type should thus be associated with a

\footnotetext{
2 Gali and Gertler (1999) assume that a fraction $\theta$ of firms, labeled 'backward looking', use a simple rule of thumb that is based on the recent pricing behavior of the firms' competitors.

${ }^{3} \kappa=(\sigma+\eta)(1-\omega)(1-\omega \beta) \phi^{-1}$ and $\phi=\omega+\theta[1-\omega(1-\beta)]$, where $\sigma$ and $\eta$ are, respectively, the consumption and the labor elasticity of substitution, $(1-\omega)$ is the fraction of firms that adjust their prices in any given period assuming Calvo price setting, and $\beta$ is the discount factor. We assume logarithmic utility function, a fraction of $40 \%$ of backward looking price setters (as in Gali-Gertler (1999) among others) and a fraction of $20 \%$ of the firms adjusting their prices in any given period.
} 
booming economy. Since such a shock has only a temporary effect on real variables, it does not depress the long term real interest rate much.

Next we review the effects of a negative shock to the Wicksellian interest. Since the shock is highly persistent in the VAR analysis, we assume that the autocorrelation coefficient is 0.95. ${ }^{4}$ Figure 4 presents the impulse response functions. Since aggregate demand depends on the difference between expected one-period real interest rate and the Wicksellian interest rate, $i_{t}-E_{t} \pi_{t+1}-\widetilde{r}_{t}$, the fall in the latter implies that monetary policy has become contractionary. This leads to a drop in the output gap and inflation. In response, the central bank cuts the nominal interest rate to prevent the further decline in the output gap and the inflation rate. The long-term real interest rate, which is given by the sum of expected future one-period rates 5 , drops on impact by a fraction of the initial drop in the nominal interest rate. These results show that an unexpected decline in the Wicksellian interest rate

\section{CONCLUSIONS}

Long real interest rates, as measured by the yield on 10-year TIPS, collapsed in the decade before the financial crisis. Our empirical and theoretical analysis suggests that this fall was associated with a fall in the Wicksellian interest rate and that the Federal Reserve responded by cutting the federal funds rate. The alternative view that monetary policy triggered a fall in long real yields seems difficult to reconcile with the VAR findings and the New Keynesian model studied here.

But irrespectively what caused central banks to cut them so far, low interest rates did play an important role in the crisis by providing an unexpectedly strong boost to financial markets activity, as suggested in the analysis of Rajan (2005). Unfortunately, central banks and other regulators appear to have vastly underestimated the risks to financial stability arising from low interest rates, even if warranted by macroeconomic considerations.

\footnotetext{
${ }^{4}$ Note that in a model without technology shocks, the Wicksellian interest rate depends entirely on the exogenous shock.

${ }^{5}$ Thus, $r_{t}^{10}=\frac{1}{n} \sum_{i=0}^{n} E_{t} r_{t+1}$.
} 


\section{REFERENCES}

Bernanke, Ben S. (2005): “Remarks by Governor Ben S. Bernanke: The Global Saving Glut and the U.S. Current Account Deficit", The Sandridge Lecture, Virginia Association of Economists, Richmond, VA, March 10.

Bernanke, Ben S. (2010), "Monetary Policy and the Housing Bubble," Lecture given at the annual meeting of the American Economic Association, Atlanta, January 3.

Gali, Jordi and Mark Gertler (1999): "Inflation dynamics: A structural econometrics analysis", Journal of Monetary Economics, 44(2): 195-222.

Lombardi, Marco J. and Silvia Sgherri (2007), “(Un)naturally Low? Sequential Monte Carlo Tracking of the US Natural Interest Rate", ECB Working Paper No. 794.

Obstfeld, Maurice and Kenneth Rogoff (2009): “Global Imbalances and the Financial Crisis: Product of Common Causes", mimeo.

Taylor, John B. (2007): “Housing and Monetary Policy,” NBER Working Paper Series 13682. Cambridge, Mass.: National Bureau of Economic Research.

Taylor, John B. (2008): “The Financial Crisis and the Policy Responses: An Empirical Analysis of What Went Wrong", NBER Working Paper Series 14631. Cambridge, Mass.: National Bureau of Economic Research.

Walsh, Carl E. (2010): Monetary Theory and Policy, MIT Press, Cambridge, Massachussets.

Woodford, Michael (2003): Interest and Prices: Foundations of a Theory of Monetary Economics, Princeton University Press, Princeton, New Jersey. 
Figure 1

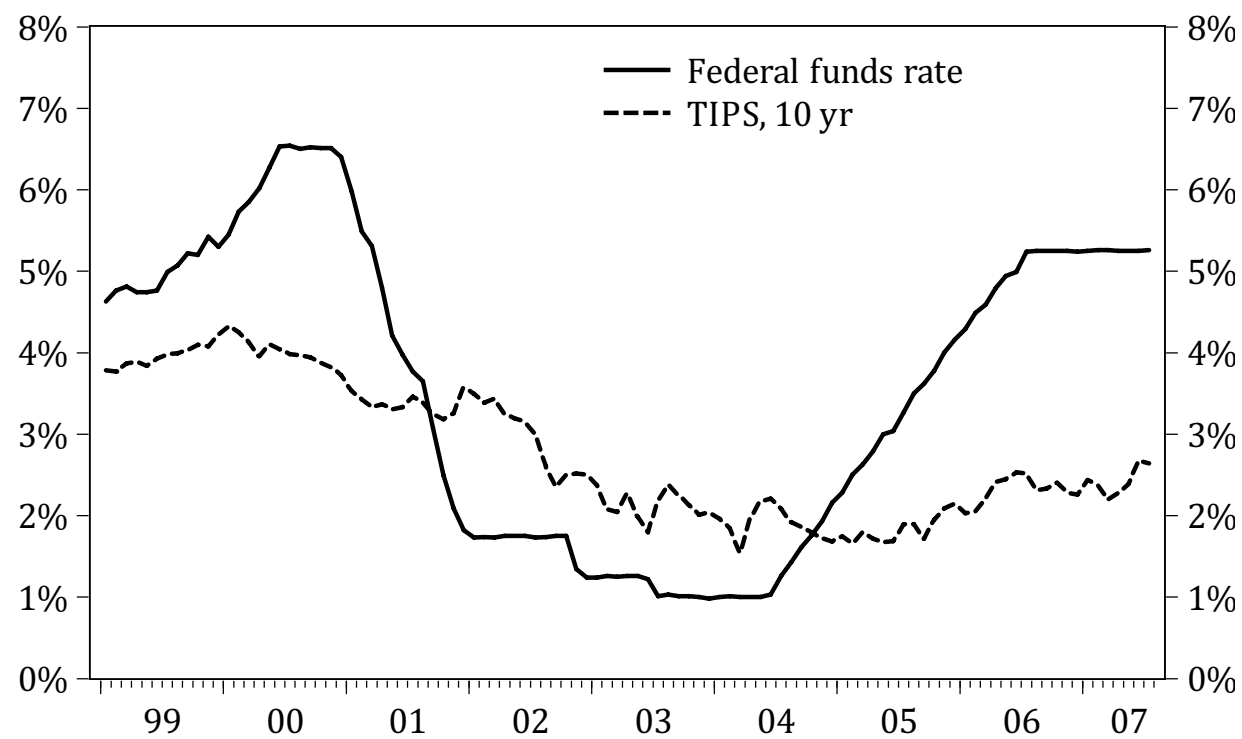

Figure 2 Impulse Responses for the VAR

Response to Cholesky One S.D. Innovations \pm 2 S.E.

Response of federal funds rate to a monetary policy shock

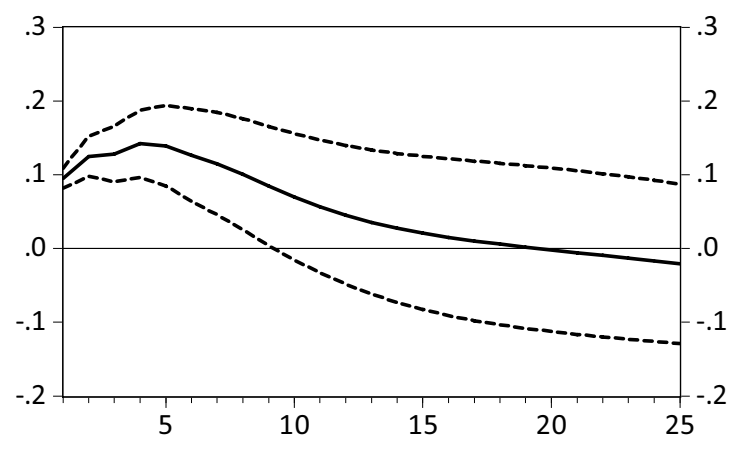

Response of 10-yr TIPS yield to a monetary policy shock

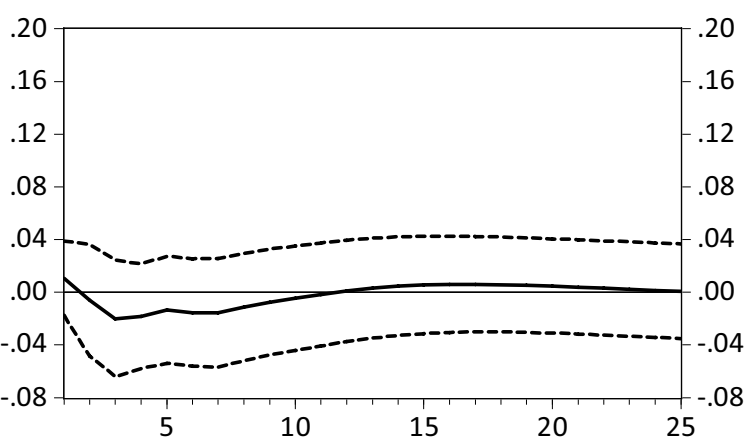

Response of federal funds rate to a TIPS shock

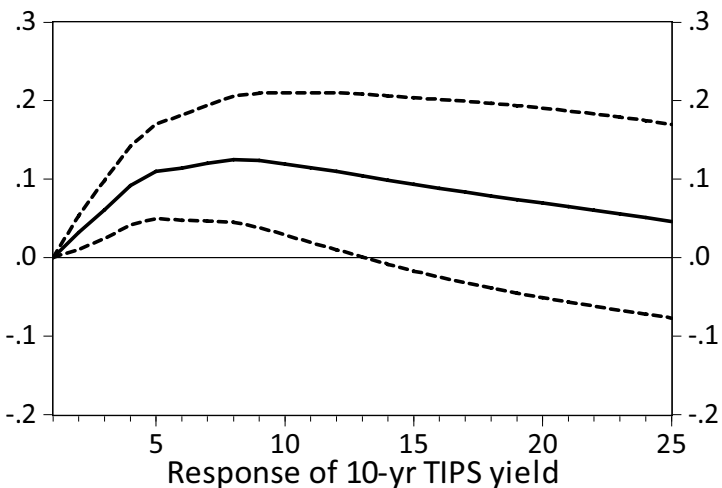

to a TIPS shock

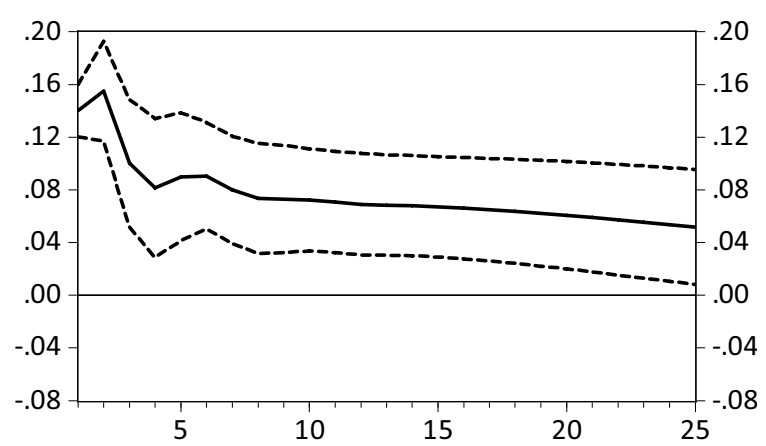


Figure 3 Impulse Response Function from New Keynesian Model; persistent negative monetary policy shock $(\rho=0.5)$.

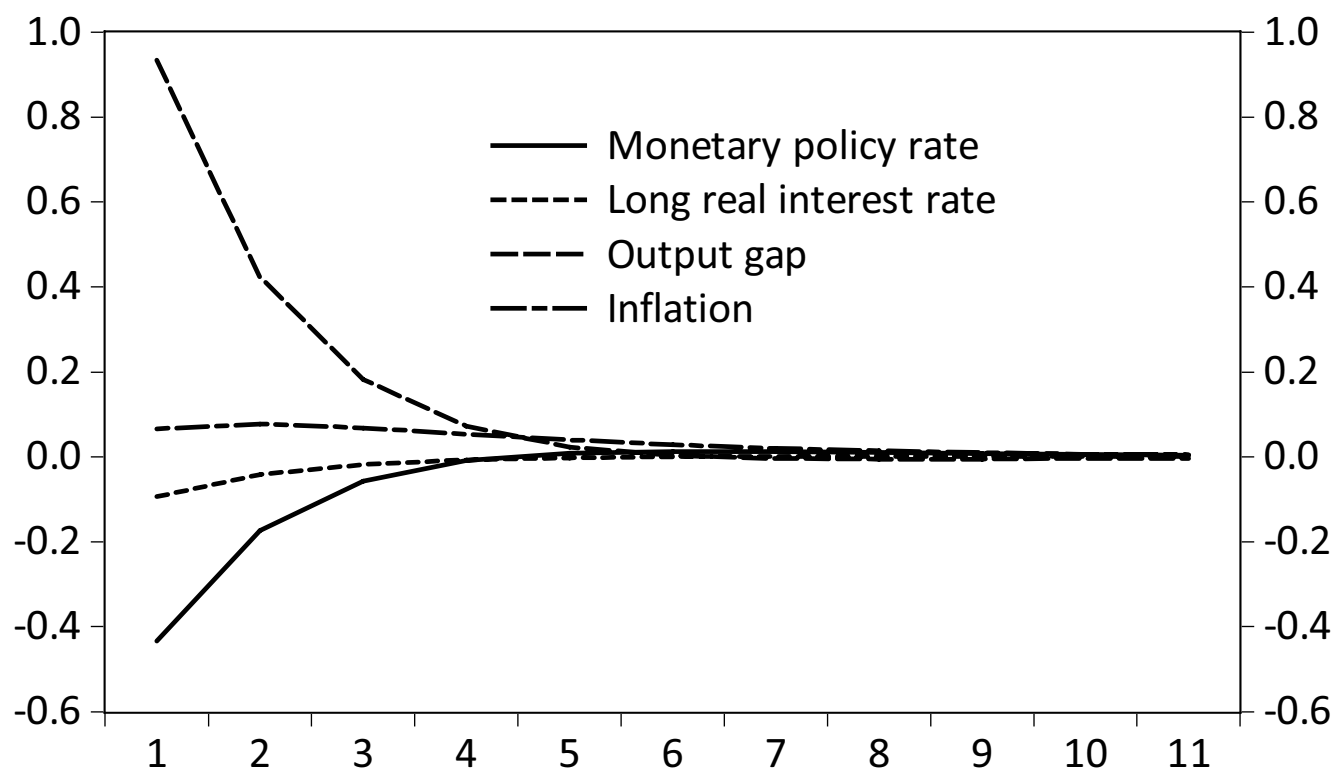

Figure 4 Impulse Response Function from New Keynesian Model; persistent negative shock to Wicksellian interest rate $(\rho=0.95)$.

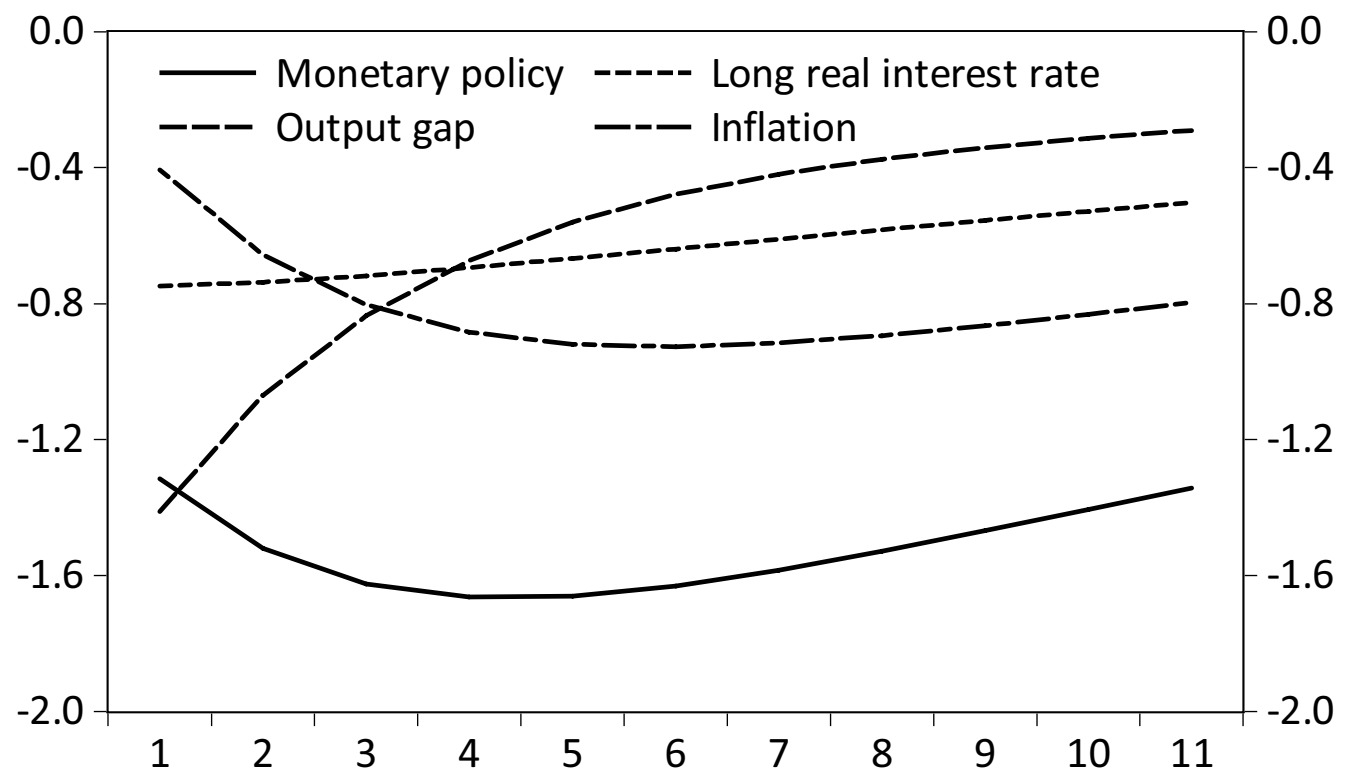




\section{CFS Working Paper Series:}

\begin{tabular}{|c|c|c|}
\hline No. & Author(s) & Title \\
\hline $2011 / 21$ & $\begin{array}{l}\text { Maarten van Rooij } \\
\text { Annamaria Lusardi } \\
\text { Rob Alessie }\end{array}$ & $\begin{array}{l}\text { Financial Literacy, Retirement Planning, and } \\
\text { Household Wealth }\end{array}$ \\
\hline $2011 / 20$ & Marcel Bluhm & $\begin{array}{l}\text { Investigating the Monetary Policy of Central } \\
\text { Banks with Assessment Indicators }\end{array}$ \\
\hline 2011/19 & $\begin{array}{l}\text { Marcel Bluhm } \\
\text { Jan Pieter Krahnen }\end{array}$ & $\begin{array}{l}\text { Default Risk in an Interconnected Banking } \\
\text { System with Endogeneous Asset Markets }\end{array}$ \\
\hline $2011 / 18$ & $\begin{array}{l}\text { Kristian Rydqvist } \\
\text { Joshua Spizman } \\
\text { llya Strebulaev }\end{array}$ & The Evolution of Aggregate Stock Ownership \\
\hline 2011/17 & $\begin{array}{l}\text { Azi Ben-Rephael } \\
\text { Jacob Oded } \\
\text { Avi Wohl }\end{array}$ & $\begin{array}{l}\text { Do Firms Buy Their Stock at Bargain Prices? } \\
\text { Evidence from Actual Stock Repurchase } \\
\text { Disclosure }\end{array}$ \\
\hline 2011/16 & $\begin{array}{l}\text { Christian Andres } \\
\text { André Betzer } \\
\text { Marc Goergen }\end{array}$ & $\begin{array}{l}\text { Dividend Policy, Corporate Control and Tax } \\
\text { Clienteles. The Case of Germany }\end{array}$ \\
\hline 2011/15 & Christopher D. Carroll & $\begin{array}{l}\text { Theoretical Foundations of Buffer Stock } \\
\text { Saving }\end{array}$ \\
\hline $2011 / 14$ & Laura Moretti & $\begin{array}{l}\text { Transparency and Emerging Market Bond } \\
\text { Spreads }\end{array}$ \\
\hline 2011/13 & Otmar Issing & $\begin{array}{l}\text { Lessons for Monetary Policy: What Should the } \\
\text { Consensus Be? }\end{array}$ \\
\hline $2011 / 12$ & Charles Goodhart & $\begin{array}{l}\text { The Emerging New Architecture of Financial } \\
\text { Regulation }\end{array}$ \\
\hline $2011 / 11$ & $\begin{array}{l}\text { Xavier Freixas } \\
\text { Christian Laux }\end{array}$ & $\begin{array}{l}\text { Disclosure, Transparency, and Market } \\
\text { Discipline }\end{array}$ \\
\hline
\end{tabular}

Copies of working papers can be downloaded at http://www.ifk-cfs.de 